\title{
The Composition of Rat Liver Microsomes
}

\author{
THE STRUCTURAL PROTEINS OF RAT LIVER MICROSOMES
}

\author{
BY K. A. WARD* AND J. K. POLLAK \\ Department of Histology and Embryology, University of Sydney, Sydney, N.S.W. 2006, Australia
}

(Received 23 January 1969)

\begin{abstract}
1. The structural-protein component of microsomal membranes was isolated by three separate methods. Analysis by polyacrylamide-gel electrophoresis indicated that the microsomal structural component is made up of a heterogeneous group of proteins. These proteins were further characterized by their phospholipid-binding capacity. The electrophoretic patterns of microsomal structural proteins were found to differ significantly from those of mitochondrial structural proteins. 2. The reticulosomal fraction was also characterized by electrophoresis with reference to total microsomal proteins, microsomal structural proteins and ribosomal proteins. The reticulosomes gave an electrophoretic pattern significantly different from those of the other three preparations examined. It is suggested that reticulosomes consist largely of enzymic proteins of the endoplasmic reticulum.
\end{abstract}

The protein moiety of many lipoprotein membranes can be fractionated to yield a component with an affinity for micellar phospholipids (Green, Tisdale, Criddle, Chen \& Bock, 1961; Richardson, Hultin \& Fleischer, 1964). This protein fraction has been termed 'structural protein', because of its apparent role in stabilizing lipoprotein complexes of biological membranes (Green et al. 1967).

Richardson et al. (1964) developed a method of obtaining mitochondrial structural protein that avoids the use of sodium dodecyl sulphate and methanol. The structural protein isolated by this method showed a great affinity for phospholipids. Richardson and co-workers also studied the phospholipid-binding properties of the structural protein under various conditions, and found that it bound four times as much phospholipid at $\mathrm{pH} 10$ as at neutral $\mathrm{pH}$ values. Urea (8 $\mathrm{M}$ ) slightly enhanced this phospholipid binding, this increase being ascribed to an unfolding of the protein by the urea with the subsequent availability of more sites for phospholipid binding. Richardson, Hultin \& Green (1963) also reported that a protein preparation with similar solubility and phospholipid-binding properties could be isolated from a variety of different membranes by applying the fractionation method proposed for mitochondrial structural protein. These membranes included liver microsomes, chloroplasts and erythrocyte 'ghosts'.

Although it was repeatedly claimed that there was one species of structural protein per organelle, and possibly one and the same structural protein for

* Present address : Department of Zoology, University of Massachusetts, Amherst, Mass. 01002, U.S.A. all organelles, only limited evidence has been presented on the protein homogeneity of these structural-protein preparations.

The homogeneity of the mitochondrial structural protein was questioned by Haldar, Freeman \& Work (1966) when the structural protein prepared from rat liver mitochondria was subjected to electrophoresis on polyacrylamide gels. The protein preparation isolated by the original method of Green et al. (1961) was found to be heterogeneous. Although the exact number of components was not stated by Haldar et al. (1966), it was 'discouragingly large'. The structural protein as prepared by the method of Richardson et al. (1964) also contained a number of components, with four major bands and at least eight minor bands.

Evidence is presented in the present paper that on solubilizing rat liver microsomes with sodium deoxycholate, it is possible to fractionate the solubilized proteins either with ammonium sulphate, or by progressive removal of the bile salt at a low protein concentration by dialysis, to yield a group of proteins that correspond to the 'structuralprotein' fraction described by other workers. When examined by electrophoresis on polyacrylamide gel the structural-protein fraction isolated from microsomes appears to be a heterogeneous mixture of proteins.

\section{MATERIALS AND METHODS}

Animals and chemicals. Female Sprague-Dawley albino rats weighing $150-180 \mathrm{~g}$. were obtained from the University of Sydney animal house and maintained on standard laboratory rat and mouse food cubes. 
All reagents used were analytical grade wherever possible. Specific information on the reagents is given below where appropriate.

Preparation of microsomal fractions. Rats were stunned and killed by cervical fracture. The liver was rapidly excised and rinsed in cold $0.25 \mathrm{M}$-sucrose. It was then blotted on filter paper, weighed and minced with scissors. Portions (2 g.) of liver were then homogenized in 5 vol. of $0.25 \mathrm{M}$-sucrose in a Teflon-glass homogenizer by using eight complete passes with the pestle. The homogenates were combined and diluted to a $10 \%(w / v)$ suspension with 0.25 M-sucrose.

Microsomes were prepared by the method of Ernster, Siekevitz \& Palade (1962). The microsomal pellets were resuspended in $0.01 \mathrm{~m}$-tris-HCl buffer ( $\mathrm{pH} \mathrm{7.2}$ at $4^{\circ}$ ), at a tissue equivalent of $200 \mathrm{mg} . / \mathrm{ml}$, and centrifuged at $105000 \mathrm{gav}$. for $60 \mathrm{~min}$. at $4^{\circ}$ in the no. 50 angle rotor of a Spinco model L 2 ultracentrifuge. The pale-amber supernatant was decanted and the pellets were rinsed, resuspended in tris buffer at a protein concentration of $20 \mathrm{mg} . / \mathrm{ml}$. and stored at $-20^{\circ}$ for $12-36 \mathrm{hr}$. This suspension was called 'washed microsomes'.

Smooth microsomes and rough microsomes were separated by the method of Dallner (1963).

Preparation of reticulosomes. Fraction II (rough microsomes) as described by Dallner (1963) was suspended in $0.01 \mathrm{M}$-tris-HCl buffer ( $\mathrm{pH} 7.1$ at $\left.2^{\circ}\right)-0.001 \mathrm{M}-\mathrm{KCl}$, and treated with a $1 \mathrm{mg}$. $/ \mathrm{ml}$. suspension of ribonuclease (Sigma Chemical Co., St Louis, Mo., U.S.A.; $5 \times$ crystallized), by using $0 \cdot 1 \mathrm{ml}$. of ribonuclease suspension $/ 200 \mathrm{mg}$. of tissue equivalents, in the presence of $0.1 \mathrm{~m}-\mathrm{EDTA}(\mathrm{pH} 7 \cdot 1)$ for $60 \mathrm{~min}$. at $2^{\circ}$. Subsequently $0.11 \mathrm{vol}$. of freshly prepared $2 \cdot 6 \%(w / v)$ sodium deoxycholate (E. Merck A.-G., Darmstadt, Germany) was added, keeping the deoxycholate/protein ratio 1-1.5. After the suspension had been gently inverted eight times it was centrifuged for $10 \mathrm{~min}$. at $37750 g_{\text {av. }}$ and the loose sediment was discarded. The supernatant was then centrifuged at $105000 \mathrm{~g}_{\mathrm{av}}$. for $60 \mathrm{~min}$. The resulting pellet was resuspended by hand homogenization in $0.25 \mathrm{M}$-sucrose, made $0.015 \mathrm{M}$ with respect to $\mathrm{CsCl}$; $3 \mathrm{ml}$. of this suspension was layered over $1.8 \mathrm{ml}$. of $1.3 \mathrm{M}$-sucrose-0.015 $\mathrm{M}-\mathrm{CsCl}$ in an $\mathrm{SW} 39 \mathrm{swing}$-out rotor and centrifuged at $130000 \mathrm{~g}_{\mathrm{av}}$. for $60 \mathrm{~min}$. The clear pellet was resuspended by hand homogenization in $0.25 \mathrm{M}$-sucrose.

Preparation of mitochondria. A $10 \%(w / v)$ liver homogenate, prepared as outlined above, was centrifuged at $1000 \mathrm{~g}_{\mathrm{av}}$. for $10 \mathrm{~min}$., the supernatant was removed with a large syringe and centrifuged at $10000 \mathrm{~g}_{\mathrm{av}}$. for $10 \mathrm{~min}$. The supernatant and the loose sediment on top of the pellet were discarded. The pellet was resuspended in $0.01 \mathrm{M}$ tris- $\mathrm{HCl}$ (pH 7.2)-0.25 M-sucrose and centrifuged again at $1000 \mathrm{~g}_{\text {av }}$. for $10 \mathrm{~min}$. The supernatant and loose sediment were discarded as before and the pellet was again resuspended in $0.01 \mathrm{M}$-tris- $\mathrm{HCl}(\mathrm{pH} \mathrm{7.2})-0.25 \mathrm{M}$-sucrose and centrifuged at $10000 \mathrm{~g}_{\mathrm{av}}$. for $10 \mathrm{~min}$. The pellet was resuspended in $0.01 \mathrm{M}$-tris- $\mathrm{HCl}(\mathrm{pH} \mathrm{7.2)}$ at a protein concentration of $20 \mathrm{mg} . / \mathrm{ml}$. and stored at $-20^{\circ}$ for $12-36 \mathrm{hr}$.

Preparation of ribosomes. Ribosomes were prepared by treating fraction II (Dallner, 1963), suspended in $0.01 \mathrm{M}$ tris-HCl buffer $\left(\mathrm{pH} \mathrm{7 \cdot 1}\right.$ at $\left.2^{\circ}\right)-0.001 \mathrm{M}-\mathrm{KCl}$, with $0.11 \mathrm{vol}$. of freshly prepared $2.6 \%(\mathrm{w} / \mathrm{v})$ sodium deoxycholate (Merck), keeping the deoxycholate/protein ratio approx. 2. The supernatant $(3.6 \mathrm{ml}$.) was then layered over a dis- continuous gradient consisting of a $2 \mathrm{M}$-sucrose cushion $(0.8 \mathrm{ml}$.) overlaid by $1.3 \mathrm{M}$-sucrose $(1 \mathrm{ml}$.). This discontinuous gradient was then centrifuged for $2 \mathrm{hr}$. at $105000 \mathrm{gav}$. in a Spinco SW 39 rotor. The pellet of ribosomes was then stored at $-20^{\circ}$ for $12-36 \mathrm{hr}$.

Isolation of structural proteins. (i) Isolation of structural protein by $6.5 \%$ saturation with $\left(\mathrm{NH}_{4}\right)_{2} \mathrm{SO}_{4}$. 'Washed microsomes' that had been stored for at least $12 \mathrm{hr}$. at $-20^{\circ}$ were thawed and adjusted to a protein concentration of $20 \mathrm{mg}$. $/ \mathrm{ml}$. with $0.01 \mathrm{M}$-tris-HCl buffer $\left(\mathrm{pH} 7.2\right.$ at $4^{\circ}$ ). Sodium deoxycholate $(2 \mathrm{mg} . / \mathrm{mg}$. of protein) was added as an aq. $5 \%(w / v)$ solution, and the slightly turbid solution was centrifuged at $105000 \mathrm{~g}_{\mathrm{av}}$. for $60 \mathrm{~min}$. to remove ribosomes, ribosomal subunits and any undissolved membranous material. The clear red supernatant was pipetted off, the last $0.5 \mathrm{ml}$. being left behind to avoid contamination of the supernatant solution with a very small fluffy layer present at the bottom of the centrifuge tube. Then $\mathrm{Na}_{2} \mathrm{~S}_{2} \mathrm{O}_{4}(2 \mu \mathrm{g}$. mg. of original protein) was added and a saturated solution of $\left(\mathrm{NH}_{4}\right)_{2} \mathrm{SO}_{4}$, adjusted to $\mathrm{pH} 7.0$ at $4^{\circ}$, was added slowly with vigorous stirring until the final suspension was $6.5 \%$ saturated with $\left(\mathrm{NH}_{4}\right)_{2} \mathrm{SO}_{4}$. After standing for $15 \mathrm{~min}$. the suspension was centrifuged for $20 \mathrm{~min}$. at $35000 \mathrm{~g}_{\mathrm{av}}$. . The slightly brown pellet was then washed twice with tris-HCl buffer and resuspended in 0.01 $\mathrm{M}$-tris- $\mathrm{HCl}$ buffer ( $\mathrm{pH} 7.2$ at $4^{\circ}$ ), at a protein concentration of $20 \mathrm{mg} . / \mathrm{ml}$.

(ii) Isolation of structural protein by removal of detergent by dialysis. 'Washed microsomes' that had been stored for at least $12 \mathrm{hr}$. at $-20^{\circ}$ were thawed and adjusted to a protein concentration of $2 \mathrm{mg} . / \mathrm{ml}$. with $0.01 \mathrm{M}$-tris- $\mathrm{HCl}$ buffer ( $\mathrm{pH} 7 \cdot 2$ at $\left.4^{\circ}\right)$. Sodium deoxycholate $(2 \mathrm{mg} . / \mathrm{mg}$. of protein) was added as an aq. $5 \%(w / v)$ solution and the solution centrifuged at $105000 \mathrm{~g}_{\mathrm{av}}$. for $60 \mathrm{~min}$. The clear red supernatant was collected as in (i) and dialysed with constant slow stirring against water $(10 \mathrm{ml}$. of 'detergent solution'/l. of water). Water was changed every $8 \mathrm{hr}$. and the precipitated proteins were collected by centrifuging the suspension for $60 \mathrm{~min}$. at $105000 \mathrm{~g}_{\mathrm{av}}$. Specific protein fractions were collected by removing dialysis bags in accordance with a graph of protein precipitated versus time of dialysis under standard conditions. The protein pellet was washed twice with $0.01 \mathrm{M}$-tris- $\mathrm{HCl}$ buffer $\left(\mathrm{pH} 7.2\right.$ at $\left.4^{\circ}\right)$ and resuspended at a protein concentration of $20 \mathrm{mg} . / \mathrm{ml}$.

Structural protein was also prepared by the method of Richardson et al. (1964).

Cholate and deoxycholate bound to the protein were removed with cold $90 \%$ acetone by the method of Richardson et al. (1964).

Solubilization of protein fractions for electrophoresis. Freeze-dried protein samples were dissolved in $99 \%(w / v)$ formic acid at a protein concentration of $1 \%(w / v)$. The formic acid was then removed by dialysis against $0.01 \mathrm{M}$-citric acid, $\mathrm{pH} 3 \cdot 3$, made $8 \mathrm{M}$ with respect to urea. The formic acid-protein solution $(0.1 \mathrm{ml} . / 20 \mathrm{ml}$. of citrate-urea) was dialysed for $4 \mathrm{hr}$. at room temperature, the citrate-urea solution being changed once after $2 \mathrm{hr}$. The protein samples were then analysed directly by electrophoresis.

Electrophoresis of protein fractions. Electrophoresis of the total protein of the microsomal membranes and the proteins isolated as fractions of these membranes was conducted by using discontinuous electrophoresis on vertical polyacrylamide-gel slabs. The electrophoresis cell was essentially a modification of the vertical unit designed by Smithies (1959) to prevent loss of resolution in starch gels due to 
electrodecantation effects. The construction and use of the cell were described in detail by Ward (1967).

A $\mathrm{pH}$ buffer system was designed by using the criteria proposed by Williams \& Reisfeld (1964) for discontinuous buffers for electrophoresis. Citrate was chosen as the gel buffer, and $\mathrm{K}^{+}$and $\beta$-alanine were used respectively as the leading and trailing ions. The $\mathrm{pH}$ of the main separating gel was 4.0 and that of the spacing gel was 5.0. This latter $\mathrm{pH}$ was about 1 unit too low to take full advantage of $\beta$-alanine as a trailing ion according to one of the criteria used, which is that for an acidic buffer system the $\mathrm{pH}$ of the spacing gel must be $2-3 \mathrm{pH}$ units above the $\mathrm{p} K_{a}$ (3.6 for $\beta$-alanine) of the trailing ion. However, as the best separation of the membrane proteins in the main separating gel was found to take place at $\mathrm{pH} 4 \cdot 0, \beta$-alanine was a good overall choice for the trailing ion.

A $15 \%(w / v)$ separating gel (pH4.0) was polymerized by mixing 1 part of solution $A$ with 2 parts of solution $B$, and 1 part of $8 \mathrm{M}$-urea and 4 parts of solution $C$ (freshly prepared). Solution $A$ consisted of $10.0 \mathrm{ml}$. of $1 \mathrm{M}-\mathrm{KOH}, 1.0 \mathrm{ml}$. of tetramethylethylenediamine, $12.0 \mathrm{~g}$. of urea and $5.5 \mathrm{ml}$. of $4 \mathrm{M}$-citric acid, diluted with water to a volume of $25 \mathrm{ml}$. Solution $B$ was made up of $15.0 \mathrm{~g}$. of acrylamide monomer, $0 \cdot 1 \mathrm{~g}$. of methylenebisacrylamide and $6 \cdot 0 \mathrm{~g}$. of urea, and water to a total volume of $25 \mathrm{ml}$. Solution $C$ consisted of $70 \mathrm{mg}$. of ammonium persulphate and $15 \mathrm{~g}$. of urea in water made up to a total volume of $25 \mathrm{ml}$.

The $1 \%(\mathrm{w} / \mathrm{v})$ spacing gel (pH5.0) was polymerized by mixing 1 part of solution $D$ with 2 parts of solution $E, 1$ part of $8 \mathrm{M}$-urea and 1 part of solution $F$. Solution $D$ consisted of $12.0 \mathrm{ml}$. of $1 \mathrm{M}-\mathrm{KOH}, 0.125 \mathrm{ml}$. of tetramethylethylenediamine, $12 \cdot 0 \mathrm{~g}$. of urea and $2.0 \mathrm{ml}$. of $4 \mathrm{M}$-citric acid, all made up with water to a volume of $25 \mathrm{ml}$. Solution $E$ was made up from $2.5 \mathrm{~g}$. of acrylamide monomer, $0 \cdot 625 \mathrm{~g}$. of methylenebisacrylamide and $12.0 \mathrm{~g}$. of urea, and water to a total volume of $25 \mathrm{ml}$. Solution $F$ was a mixture of $1.0 \mathrm{mg}$. of riboflavin and $12 \cdot 0 \mathrm{~g}$. of urea dissolved in water and made up to $25 \mathrm{ml}$.

The tray buffer (pH5.1) consisted of $31 \cdot 6 \mathrm{~g}$. of $\beta$-alanine, $40.0 \mathrm{ml}$. of $0.1 \mathrm{M}$-sodium citrate and $10.0 \mathrm{ml}$. of $0.1 \mathrm{M}$-citric acid, all diluted to 11 . with water.

All gels were made $8 \mathrm{M}$ with respect to urea. Protein samples $(700 \mu \mathrm{g}$.) were separated with a current of $6 \mathrm{~mA}$ for $16 \mathrm{hr}$. The gel was then removed from the electrophoresis unit and stained in a solution of $1 \%$ Naphthalene Black $10 \mathrm{~B}$ in $7 \%(\mathrm{w} / \mathrm{v})$ acetic acid for $20 \mathrm{~min}$. with constant gentle shaking. Background stain was removed by exhaustive washing in $7 \%$ acetic acid. The gels were then photographed by transmitted light on Kodak microfile film by immersing the gel in 7\% acetic acid in a glass Petri-dish lid.
Binding of glucose 6-phosphatase to structural protein. Structural protein (freshly prepared or freeze-dried) was resuspended in $0.01 \mathrm{M}$-tris-HCl buffer $\left(\mathrm{pH} 7.2\right.$ at $\left.4^{\circ}\right)$, at a protein concentration of $1 \mathrm{mg} . / \mathrm{ml}$., and mixed with an equal volume of 'solubilized microsomes', prepared as described below. After $15 \mathrm{~min}$. at $4^{\circ}$ the suspension was centrifuged at low speed, the pellet washed four times with tris$\mathrm{HCl}$ buffer (pH 7.2) and resuspended in $\mathrm{NaOH}-$ maleate buffer $\left(\mathrm{pH} 6.5 \mathrm{at}^{\circ}\right)$ at a protein concentration of $1 \mathrm{mg} . / 0.1 \mathrm{ml}$. Glucose 6-phosphatase activity was assayed by the method of Swanson (1955). The reaction was stopped by the addition of $0.5 \mathrm{ml}$. of $10 \%(\mathrm{w} / \mathrm{v}) \mathrm{HClO}_{4}$, and inorganic phosphate was determined in suitable samples by the method of Chen, Toribara \& Warner (1956). Non-specific phosphatase activity was determined by the substitution of $\beta$-glycerophosphate for glucose 6-phosphate as substrate.

'Solubilized microsomes' were prepared by resuspending a microsomal pellet, prepared as described above in $0.01 \mathrm{M}$ tris- $\mathrm{HCl}$ buffer ( $\mathrm{pH} \mathrm{7 \cdot 2} \mathrm{at} 4^{\circ}$ ), at a concentration of $200 \mathrm{mg}$. of tissue equivalents/ml., and adding 1 vol. of an aq. $2.6 \%$ $(w / v)$ solution of sodium deoxycholate $/ 9 \mathrm{vol}$. of suspension to give a final concentration of $0 \cdot 26 \%(w / v)$ sodium deoxycholate. Insoluble material, ribosomes and undissolved membrane fragments were removed by centrifuging for $60 \mathrm{~min}$. at $105000 \mathrm{~g}_{\mathrm{av} .}$. The supernatant was collected and used immediately as 'solubilized microsomes'.

Chemical determinations. Protein was determined by the method of Pollak \& Shorey (1964) or the method of Lowry, Rosebrough, Farr \& Randall (1951). Bovine serum albumin (Sigma Chemical Co.) was used as standard. Phospholipid was determined as described by Pollak \& Ward (1967). Deoxycholate was determined by the method of Mosbach, Kalinsky, Halpern \& Kendall (1954), with sodium deoxycholate (Merck) as standard.

\section{RESULTS}

Comparison of methods for the isolation of structural protein. The yields of structural protein isolated from microsomes and mitochondria by methods $(a)$ and $(b)$ of ammonium sulphate precipitation are shown in Table 1. The yield of structural proteins from microsomes by $6.5 \%$ saturation with ammonium sulphate (method $b$ ) was more than twice that given by $12 \%$ saturation with ammonium sulphate (method $a)$. The evidence that all the proteins isolated by method (b) are structural proteins is presented below. The two methods were also

\section{Table 1. Precipitation of membrane proteins with ammonium sulphate}

The results are expressed as the means, with the results of individual experiments in parentheses. Analyses were carried out as described in the Materials and Methods section.

\begin{tabular}{lcclc}
\multicolumn{1}{c}{ Membrane } & Method & $\begin{array}{c}\text { Concn. of }\left(\mathrm{NH}_{4}\right)_{2} \mathrm{SO}_{4} \\
\text { (\% saturation) }\end{array}$ & \multicolumn{1}{c}{ Detergent } & Yield (\% of total protein) \\
Microsomes & $($ a $)$ & 12 & Deoxycholate+cholate & $6 \cdot 8(5 \cdot 5,6 \cdot 6,8 \cdot 1,6 \cdot 9)$ \\
Microsomes & $($ b) & $6 \cdot 5$ & Deoxycholate & $15 \cdot 3(16 \cdot 3,13 \cdot 7,15 \cdot 8,15 \cdot 2)$ \\
Mitochondria & $($ a $)$ & 12 & Deoxycholate+cholate & $21 \cdot 2(20 \cdot 4,22 \cdot 1,21 \cdot 2)$ \\
Mitochondria & $($ b $)$ & 6.5 & Deoxycholate & $16 \cdot 6(16 \cdot 8,16 \cdot 3)$
\end{tabular}




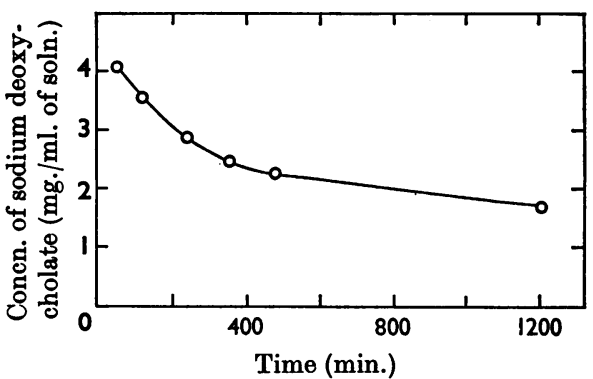

Fig. 1. Decrease in deoxycholate concentration of a 'detergent solution' dialysed against water. For details see the Materials and Methods section and the text.

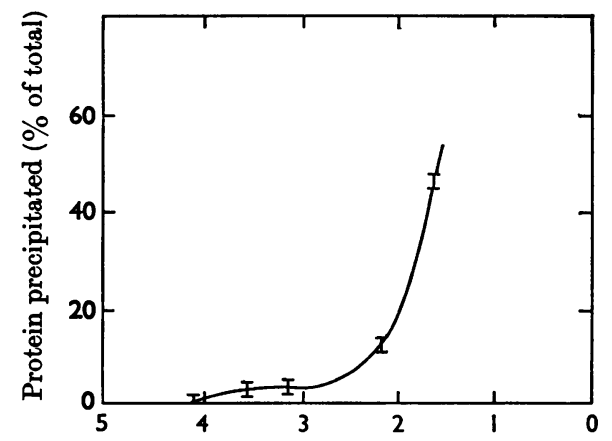

Concn. of sodium deoxycholate (mg./ml. of soln.)

Fig. 2. Precipitation of membrane proteins from a 'detergent solution'. Precipitation takes place on lowering the detergent concentration by dialysis (see Fig. 1). Each point represents the mean of two experiments and the ranges of values are indicated.

applied to the isolation of mitochondrial structural protein. Method (b) gave a lower yield of protein than did method $(a)$, and as was to be expected from the results of Watson \& Siekevitz (1956) a considerable amount of material remained insoluble after treatment with deoxycholate only. Although not investigated in detail, results of electrophoresis indicated that the proteins isolated from mitochondria by methods $(a)$ and $(b)$ were not the same.

The third method for isolating structural proteins from microsomal membranes involved slow removal of the detergent by dialysis. To achieve reproducible results from this method it was necessary to keep the ratio of the volume of 'detergent solution' to that of external water constant and to maintain always a slow even rate of stirring of the water. The results shown in Figs. 1 and 2 indicate that no protein precipitation took place above a sodium deoxy-

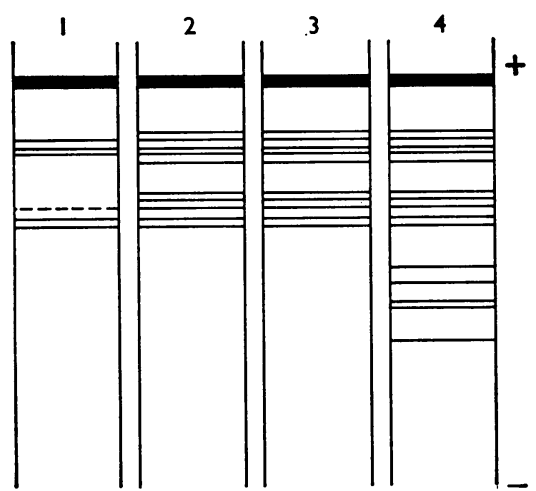

Fig. 3. Diagram of the electrophoretic patterns of the protein fractions isolated by the removal of detergent by dialysis. Protein fractions $1,2,3$ and 4 were isolated at sodium deoxycholate concentrations of $4 \cdot 0,3 \cdot 6,3 \cdot 1$ and $2 \cdot 3 \mathrm{mg}$. $/ \mathrm{ml}$. respectively. Each line represents a single band.

cholate concentration of $4 \cdot 1 \mathrm{mg} \cdot / \mathrm{ml}$. Below this concentration the microsomal membrane proteins were gradually precipitated in an approximately sequential fashion, as shown by results of electrophoresis (Fig. 3).

Phospholipid binding by structural protein. The ability of the various protein fractions to bind microsomal micellar phospholipid is shown in Table 2. It was found that the amount of phospholipid bound by the protein preparations was to some extent dependent on the particular preparation of phospholipid. This was presumably caused by slightly different states of dispersion of the various phospholipid preparations. This is indicated in Table 2, where the values obtained with phospholipid preparation $(a)$ are slightly lower than those obtained with phospholipid preparation $(b)$.

The structural proteins prepared by precipitation with $12 \%$ saturation with ammonium sulphate bound between one-fifth and one-quarter their weight of micellar phospholipid, whereas the proteins prepared by precipitation with $6.5 \%$ saturation with ammonium sulphate bound about half their weight of micellar phospholipid. As isolated, the protein had a negligible endogenous phospholipid value.

When the structural proteins were sequentially precipitated by removing the detergent by dialysis, the early fractions bind phospholipid, as shown in Table 2. Fractions 1 and 2 showed a high value for endogenous phospholipid compared with the proteins isolated by ammonium sulphate. The abilities of fractions 1, 2 and 3 to bind phospholipid were similar, whereas fraction 4 showed a decreased phospholipid-binding ability.

The ability of microsomal structural proteins to 
Table 2. Binding of phospholipid by structural proteins at $\mathrm{pH} 7 \cdot 2$

Freeze-dried structural protein, resuspended at a concentration of $1 \mathrm{mg} . / \mathrm{ml}$., was treated with twice its weight of micellar phospholipid (prepared by a modification of the method of Pollak et al. 1966) by incubating at $30^{\circ}$ for $20 \mathrm{~min}$.). The suspension was then centrifuged at $105000 \mathrm{~g}$ for $30 \mathrm{~min}$., the pellet was rinsed twice and precipitated with $5 \%(w / v) \mathrm{HClO}_{4}$. Bound phospholipid was extracted and determined as described by Pollak \& Ward (1967). The results are expressed as mean values, with the results of individual experiments in parentheses. $(a)$ and $(b)$ refer to the results obtained with two separate phospholipid preparations.

Method of isolation

$12 \%$-Satd. $\left(\mathrm{NH}_{4}\right)_{2} \mathrm{SO}_{4}$ deoxycholate + cholate

$6 \cdot 5 \%$-Satd. $\left(\mathrm{NH}_{4}\right)_{2} \mathrm{SO}_{4}+$ deoxycholate

Removal of deoxycholate by dialysis

Fraction 1

Fraction 2

Fraction 3

Fraction 4

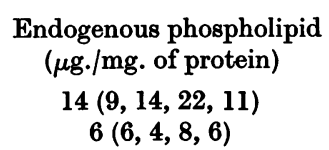

$525(519,531)$

$159(161,156)$

$27 \cdot 6(27 \cdot 4,27 \cdot 8)$

$32 \cdot 5(32 \cdot 7,32 \cdot 2)$
Total phospholipid bound after incubation with phospholipid ( $\mu \mathrm{g} . / \mathrm{mg}$. of protein)

(a) $202(202,202)(b) 248(250,246)$

(a) $526(530,521)(b) 570(567,574)$

$1446(1492,1399)$

$1128(1191,1065)$

$991(972,1010)$

$774(863,685)$
Table 3. Effect of $\mathrm{pH}$ on the phospholipid-binding ability of structural proteins

Freeze-dried structural protein was resuspended at the appropriate $\mathrm{pH}$ at a concentration of $1 \mathrm{mg} . / \mathrm{ml}$., incubated with twice its weight of micellar phospholipid at $30^{\circ}$ for $20 \mathrm{~min}$. and the $\mathrm{pH}$ of the solution was then adjusted to pH 7.2. The suspension was then treated as described in Table 2. The results are expressed as mean values, with the results of individual experiments in parentheses. The same phospholipid preparation was used throughout.

$\begin{array}{rcc} & \text { Phospholipid bound }(\mu \mathrm{g} . / \mathrm{mg} . \text { of protein }) \\ \text { pH } & \text { No urea } & 8 \mathrm{M} \text {-Urea } \\ 3.0 & 2670(2590,2750) & 1975(1970,1980) \\ 7 \cdot 2 & 570(567,574) & 405(460,350) \\ 10 \cdot 0 & 125(111,138) & 108(106,109)\end{array}$

bind phospholipid under different $\mathrm{pH}$ conditions in the presence and absence of $8 \mathrm{M}$-urea is shown in Table 3. The amount of phospholipid bound at pH 3 was five times the amount bound at noutral $\mathrm{pH}$ and about 20 times that bound at alkaline $\mathrm{pH}$. The effect of $8 \mathrm{M}$-urea was to decrease this binding capacity by approx. $20 \%$. Two separate preparations of structural proteins, both prepared by precipitation by $6.5 \%$ saturation with ammonium sulphate, were examined. The endogenous boundphospholipid value for both preparations was $6 \mu \mathrm{g}$. of phospholipid/mg. of protein.

No evidence of vesicle formation could bo found. This may be contrasted with the properties of reticulosomes (Pollak \& Shorey, 1964; Pollak, Ward \& Shorey, 1966; Pollak, 1968). Reticulosomes are particulate, but after the addition of phospholipid the reticulosomes can be seen to have formed twodimensional sheets that form vesicles. Interspersed between the vesicles are aggregates of residual protein.

Electrophoretic patterns of structural proteins. Structural proteins isolated from microsomal membranes by either $12 \%$ or $6.5 \%$ saturation with ammonium sulphate were found to be heterogeneous when examined by electrophoresis. The protein prepared by either method could be resolved into the same pattern, consisting of eight major bands (Plate 1). The largest of these bands consisted of material that did not migrate into the $15 \%$ gel. This material also did not enter the $7.5 \%$ gel and was probably aggregated material. Densitometer traces of the stained gel, although somewhat unsatisfactory because of an uneven background, gave estimates that the band accounted for $20-40 \%$ of the total protein on the gel.

The microsomal structural proteins consisted predominantly of some of the slower-migrating bands of the whole microsomal membrane pattern (Plate 1). The bands that corresponded to the microsomal structural proteins were nos. $1,4,5,7$, 8,10 and 14-15, the last two bands combined as a single diffuse band in the microsomal structuralprotein pattern.

The microsomal proteins were precipitated from solution by removing the detergent solution by dialysis; Fig. 3 shows the electrophoretic pattern of the protein fractions isolated. The concentrations of sodium deoxycholate at which protein fractions $1,2,3$ and 4 were isolated were respectively $4 \cdot 0,3 \cdot 6$, $3 \cdot 1$ and $2 \cdot 3 \mathrm{mg} . / \mathrm{ml}$. Although the first fraction consisted of only a part of the structural protein pattern, fractions 2 and 3 consisted predominantly of the structural-protein pattern isolated by precipitation with ammonium sulphate, although three additional bands were present. Fraction 4 consisted of a mixture of the structural-protein 
bands and other membrane-protein bands found in the pattern of whole microsomes, and indicated that at this stage many of the membrane proteins were being precipitated together.

The protein fraction obtained from mitochondria by treatment with $\mathbf{0 . 5} \%$ sodium deoxycholate and $6.5 \%$ saturation with ammonium sulphate was compared with microsomal structural protein (Plate 1). The mitochondrial-protein pattern, consisting of 15 major bands, was different from the microsomal structural-protein pattern. The significance of this result is discussed below. The electrophoretic pattern of reticulosomes is shown in Plate 2 , and consisted of 20 major components. These bands corresponded largely to the faster-migrating bands found in the electrophoretic pattern of whole microsomes. Three additional bands, shown by arrows in Plate 2, were clearly visible in the reticulosome pattern, but were not resolved in the whole microsomal-protein pattern, suggesting that the proteins responsible for these bands have been concentrated in the reticulosome fraction. The bands corresponding to the structural proteins of the microsomal membranes were present in the reticulosome pattern in a very low amount. This may be correlated with a much increased specific activity of some of the microsomal enzymes in reticulosome particles, notably glucose 6-phosphatase (J. K. Pollak, K. A. Ward \& T. Hallinan, unpublished work; J. K. Pollak \& M. Woog, unpublished work).

The electrophoretic pattern of the aggregated protein precipitate that was removed during the preparation of reticulosome particles ("fraction II RDS ') (Plate 2) was very similar to the reticulosome pattern. However, bands 1, 8, 9, 27 and 28 were much more prominent than in the reticulosome pattern, whereas the intensity of band 12 was slightly less in the 'fraction II RDS' pattern than in the reticulosome pattern. This result suggests that 'fraction II RDS' was of membrane origin and was formed by denaturation and aggregation of some of the membrane proteins during the procedure for the isolation of the reticulosome particles.

The electrophoretic pattern of the proteins of ribosomes isolated from normal rat liver is shown in Plate 3. The pattern, consisting of 30 major bands, was different from the reticulosome-protein pattern. Although occasional bands did correspond between the two patterns this was most likely to be due to chance matching owing to the complexity of the proteins of both samples.

Binding of glucose 6-phosphatase by structural proteins. Table 4 shows the extent to which glucose 6-phosphatase can be bound by microsomal structural protein. The amount of enzyme bound (as assayed by enzymic activity) by the structural protein was variable between experiments and
Table 4. Binding of glucose 6-phosphatase to structural protein

The number of times the structural protein-enzyme complex was washed with tris- $\mathrm{HCl}$ buffer is indicated in the first column. Because of the variable amounts of enzyme bound, the results of individual experiments are shown.

Activity ( $\mu$ g. of $P_{1}$ released $/ 20 \mathrm{~min} . / \mathrm{mg}$. of protein)

$\begin{array}{cccc}\text { No. of washes } & \text { Expt. 1 } & \text { Expt. 2 } & \text { Expt. 3 } \\ 1 & 1.04 & 1.94 & 2.38 \\ 2 & 0.76 & 1.50 & 1.80 \\ 3 & 0.69 & 1.35 & 1.63 \\ 4 & 0.68 & 1.35 & 1.62\end{array}$

seemed to depend on the activity of the enzyme originally added. It was found necessary to wash the pellet of the structural-protein-enzyme complex three times before a stable value for amount of bound enzyme was reached. In each instance this was about two-thirds of the value after the first wash. No enzyme activity was detectable when heat-denatured bovine serum albumin was substituted for microsomal structural protein, and no precipitation of the solubilized membrane proteins occurred from the detergent solution over a period of $8 \mathrm{hr}$. at $4^{\circ}$.

\section{DISCUSSION}

A membrane structural protein was defined by Criddle, Bock, Green \& Tisdale (1962) as a nonenzymic protein insoluble in aqueous solution at neutral $\mathrm{pH}$ but soluble in solutions containing reagents that disrupt hydrophobic bonds. Such proteins tend to form irregular three-dimensional polymeric aggregates and show a strong affinity for phospholipids. By this definition the proteins isolated by precipitation with ammonium sulphate are membrane structural proteins. The yield of these proteins from a detergent-solubilized membrane solution is dependent on the choice of detergents used to solubilize the membrane components. The results in Table 1 indicate that the use of deoxycholate alone as the solubilizing agent for microsomal membranes might result in a better separation of the structural proteins from the remaining membrane proteins. A greater yield of structural protein can be isolated from the solution of microsomal membrane proteins by using deoxycholate as the sole detergent, and a lower concentration of ammonium sulphate is then required. The result that the protein prepared by either method produces the same pattern when examined by polyacrylamide-gel electrophoresis is considered 

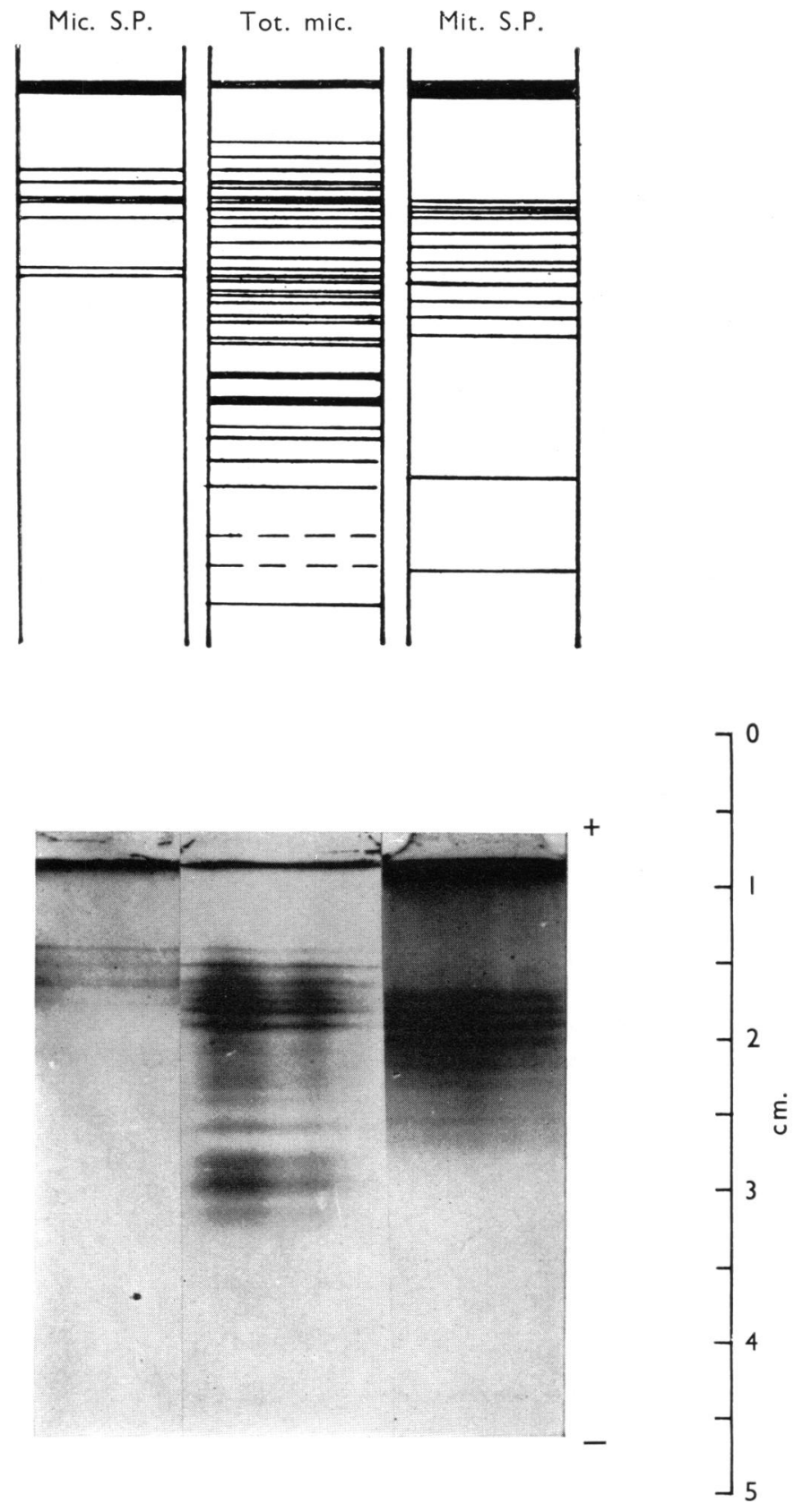

EXPLANATION OF PLATE I

Diagrammatic representations and photographs of electrophoretic patterns of microsomal structural protein (Mic. S.P.), total microsomal membrane proteins (Tot. mic.) and mitochondrial structural protein (Mit. S.P.). For details see the Materials and Methods section and the text. 

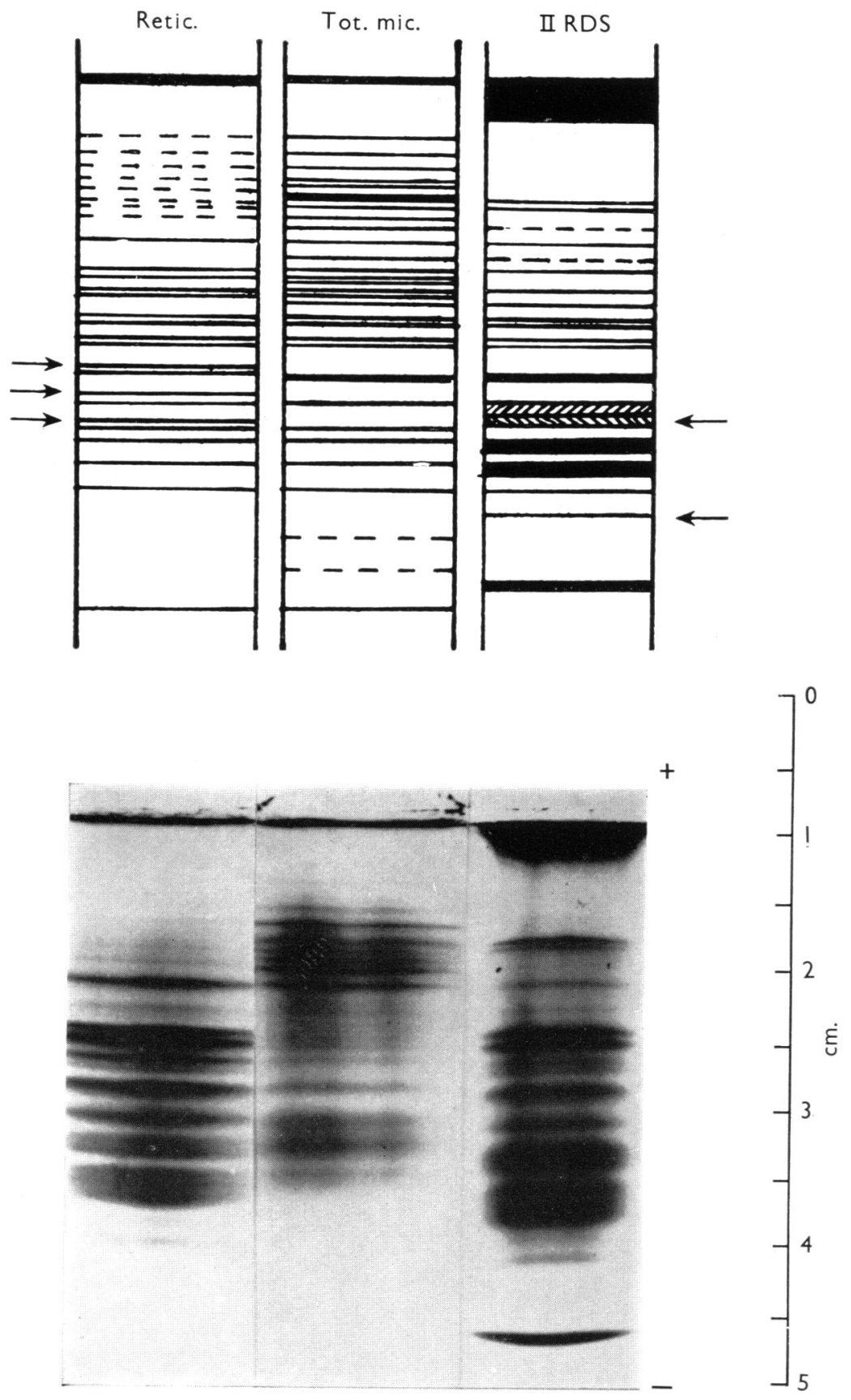

EXPLANATION OF PLATE 2

Diagrammatic representations and photographs of electrophoretic patterns of reticulosomal proteins (Retic.), fraction II RDS and total microsomal membrane proteins (Tot. mic.) 
Retic. Ribos.
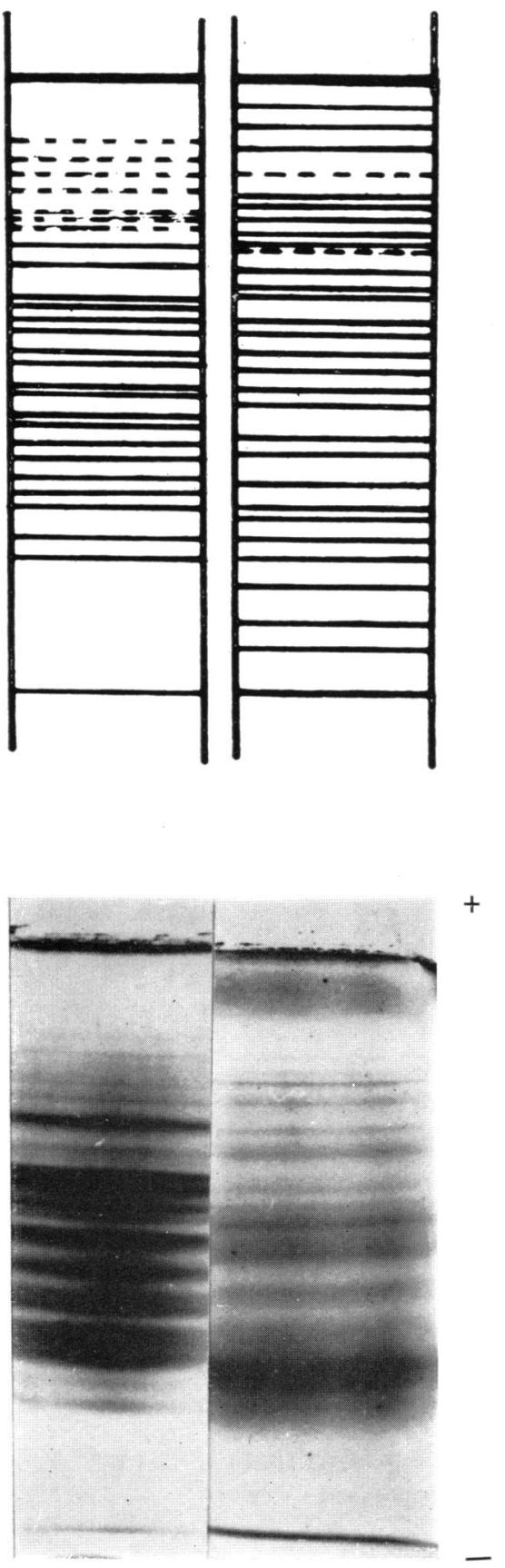

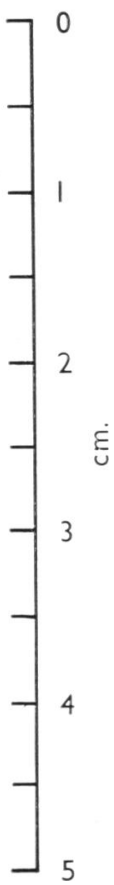

EXPLANATION OF PLATE 3

Comparison of diagrammatic representations and photographs of electrophoretic patterns obtained from ribosomal proteins (Ribos.) and reticulosomal proteins (Retic.). 
good evidence that the same proteins are being isolated by the two methods. 'The possibility remains that by increasing the ammonium sulphate concentration while using a deoxycholate-cholate detergent mixture the same yield of structural proteins may be obtained. However, the use of cholate (Table 2) tends to destroy the phospholipidbinding ability of these proteins.

In view of the property of structural proteins to remain in solution only in the presence of a reagent that disrupts hydrophobic bond interaction, it seemed possible that the progressive slow removal of the detergent from the solution of solubilized membrane protein by dialysis might result in the precipitation of the structural proteins before the other membrane proteins. That this does happen in the early stages of protein precipitation is shown in Figs. 2 and 3. The fact that the same structural proteins that are isolated from microsomal membranes by precipitation with ammonium sulphate can also be isolated by simply lowering the detergent concentration suggests that the proteins are not simply enzyme proteins denatured by the ammonium sulphate used to isolate them. The possibility that they are enzyme proteins that have been denatured by the detergent treatment cannot, however, be entirely excluded.

The results obtained by electrophoresis on polyacrylamide gels show that, regardless of the method used to prepare the structural proteins, the preparations always consist of a number of components, and it seems very unlikely that there is a single structural protein. The evidence suggests that there is a class of structural proteins present in microsomal membranes. As pointed out above, evidence has been presented by Haldar et al. (1966) that questions the concept of a single type of structural-protein molecule in mitochondrial membranes, as proposed by Criddle et al. (1962) and Criddle, Edwards \& Peterson (1966). The possibility that the many components of the microsomal structural-protein preparation are artifacts caused by the various residual compounds remaining in the polyacrylamide gels seems most unlikely. It has been shown that the presence of residual ammonium persulphate in polyacrylamide gels can cause a homogeneous protein preparation to give two bands on electrophoretic examination (Brewer, 1967), but there are no reports of a single protein producing a pattern consisting of eight major bands. The other possibility is that the heterogeneity of the preparation is due to reversible or irreversible aggregation of a single protein species in a monomer-polymer fashion. Aggregation does undoubtedly occur at acid pH as evidenced by the protein material that will not enter the main separating gel in Fig. 3 and Plate 1.

The initial binding of phospholipid by a structural-protein preparation is $\mathrm{pH}$-dependent (Table
3) and this is presumably due to ionic-force interactions between positively charged amino groups of the protein molecules and the negatively charged phosphate groups of the phospholipids. As the $\mathrm{pH}$ increases from 3 to 7 , the positive charges of the amino groups will become partially shielded by nearby negatively charged carboxyl groups, thereby decreasing their effectiveness in attracting negative charges from free solution. The continued decrease in bound phospholipid when the $\mathrm{pH}$ is raised from 7 to 10 supports this view because at $\mathrm{pH} 10$ both the protein and the phospholipid molecules are predominantly negatively charged. Once the initial binding has taken place, subsequent adjustment of the $\mathrm{pH}$ from either extreme to a neutral value does not result in the binding of the same amount of phospholipid as is bound when the initial binding takes place at neutral $\mathrm{pH}$. This can only mean that the phospholipid-protein complex, once formed, is stabilized by forces other than ionic forces. As expected, the nature of the phospholipid binding with respect to $\mathrm{pH}$ depends on the source of phospholipid. Richardson et al. (1963) found that more phospholipid was bound at alkaline $\mathrm{pH}$ than at neutral $\mathrm{pH}$ when azolectin, a soya-bean phospholipid preparation, was used.

The possibility that the increased binding of the phospholipids at acidic $\mathrm{pH}$ is due to the unfolding of the proteins to allow greater access to binding sites is not supported by the results obtained in the presence of $8 \mathrm{M}$-urea. In all cases the presence of $8 \mathrm{M}$-urea decreases the amount of phospholipid bound by the protein when the suspension is adjusted back to neutral $\mathrm{pH}$ (Table 3). This is contrary to the findings of Richardson et al. (1963), who found that $8 \mathrm{M}$-urea increased the amount of phospholipid bound by their structural-protein preparations.

The ability of the microsomal structural-protein preparation to bind the enzyme glucose 6-phosphatase indicates that these proteins may be able to form complexes with microsomal enzymes in a similar way to that in which the protein or proteins that make up the mitochondrial structural-protein preparation can bind many of the mitochondrialmembrane enzymes. Although the amount of glucose 6-phosphatase bound is very small this is probably due to the aggregated nature of the structural-protein preparation at $\mathrm{pH} 7 \cdot 2$, when most binding sites for the enzyme would be hidden. It was not found possible to make the structural proteins in a soluble form react with the glucose 6-phosphatase because the conditions required to maintain the structural proteins in solution also rapidly inactivated the enzyme. Criddle et al. (1962) found that the binding of cytochromes by mitochondrial structural-protein preparations was decreased to a low value when the structural-protein 
preparations were in polymeric or aggregated form rather than in the monomeric or soluble form.

The role of reticulosome particles in the structure of microsomal membranes has been clarified to some extent by the electrophoretic patterns shown in Plate 2. The reticulosome particle was originally proposed as a precursor unit of microsomal membranes (Pollak \& Shorey, 1964), and it was assumed that most of the proteins of the endoplasmic reticulum would be found in these granules. The results of electrophoresis, however, indicate that the reticulosome granules consist predominantly of proteins other than the structural proteins of the microsomes. It seems probable that the proteins of the reticulosome granules are predominantly the enzymically active proteins of the endoplasmic reticulum. This view is supported, at least for one enzyme, by the extremely high specific activity of the microsomal enzyme glucose 6-phosphatase found in the reticulosome particle (J. K. Pollak \& M. Woog, unpublished work). The reticulosome granules undoubtedly consist of membrane proteins. The possibility that they originate predominantly from ribosomal proteins is compatible neither with the electrophoresis results shown in Plate 3 nor with their enzymic activity.

During the preparation of reticulosome particles a small quantity of amorphous protein is removed by centrifugation. This protein mixture, designated 'fraction II RDS', consists of a mixture of proteins that are similar to those that constitute the reticulosome granules, although as shown in Plate 2 several of the components are present in different concentrations in the two preparations. It has been shown that 'fraction II RDS', although having a capacity to bind phospholipids in a similar manner to reticulosome granules, is not able to form membranous vesicles (J. K. Pollak, unpublished work). The reticulosome granules are able to form membranous vesicles (Pollak et al. 1966; Pollak, 1968). This indicates that 'fraction II RDS' consists of aggregated membrane proteins, derived either from intact membranes or from reticulosome granules, that have been denatured during the isolation of the reticulosome granules. This view is supported by the finding that the glucose 6-phosphatase activity of 'fraction II RDS' is very low (J. K. Pollak, unpublished work).

The ability of reticulosome particles to combine with phospholipids and form membranous vesicles supports the view of Green et al. (1967) that membrane-enzyme proteins, in the form of macromolecular assemblies as envisaged by Schmitt (1963), can combine together to form membranous vesicles. The presence of structural proteins is not necessary for this interaction to take place. However, in view of the results of Kagawa \& Racker
(1966), indicating that mitochondrial structuralprotein preparations have a modulator effect on certain mitochondrial enzymes, it is possible that the structural proteins may have a similar role in microsomal membranes. The structural proteins would thus be capable of causing conformational changes in the enzyme proteins and hence a change in enzyme activities.

This work was supported by the Australian Research Grants Committee, the National Health and Medical Research Council and the New South Wales State Cancer Council. A research studentship to K.A.W. from the New South Wales State Cancer Council is gratefully acknowledged.

\section{REFERENCES}

Brewer, J. H. (1967). Science, 156, 256.

Chen, P. S., Toribara, T. Y. \& Warner, H. (1956). Analyt. Chem. 28, 1756.

Criddle, R. S., Bock, R. M., Green, D. E. \& Tisdale, H. D. (1962). Biochemistry, 1, 827.

Criddle, R. S., Edwards, D. L. \& Peterson, T. G. (1966). Biochemistry, $5,578$.

Dallner, G. (1963). Acta path. microbiol. scand. Suppl. no. 166, p. 1.

Ernster, L., Siekevitz, P. \& Palade, G. E. (1962). J. Cell Biol. 15, 541 .

Green, D. E., Allman, D. W., Bachmann, E., Baum, H., Kopaczyk, K., Korman, E. F., Lipton, S., MacLennan, D. H., McConnell, D. G., Perdue, J. F., Rieske, J. S. \& Tzagoloff, A. (1967). Arch. Biochem. Biophys. 119, 312.

Green, D. E., Tisdale, H. D., Criddle, R. S., Chen, P. Y. \& Bock, R. M. (1961). Biochem. biophys. Res. Commun. 5, 109.

Haldar, D., Freeman, K. \& Work, T. S. (1966). Nature, Lond., 211, 9.

Kagawa, Y. \& Racker, E. (1966). J. biol. Chem. 241, 2467.

Lowry, O. H., Rosebrough, N. J., Farr, A. L. \& Randall, R. J. (1951). J. biol. Chem. 198, 265.

Mosbach, E. H., Kalinsky, H. J., Halpern, E. \& Kendall, F. E. (1954). Arch. Biochem. Biophys. 51, 402.

Pollak, J. K. (1968). Biochem. J. 109, 40P.

Pollak, J. K. \& Shorey, C. D. (1964). Biochem. J. 83, 36c.

Pollak, J. K. \& Ward, D. B. (1967). Biochem. J. 103, 730.

Pollak, J. K., Ward, K. A. \& Shorey, C. D. (1966). J. molec. Biol. 16, 564.

Richardson, S. H., Hultin, H. O. \& Fleischer, S. (1964). Arch. Biochem. Biophys. 105, 254.

Richardson, S. H., Hultin, H. O. \& Green, D. E. (1963). Proc. nat. Acad. Sci., Wash., 50, 821.

Schmitt, F. O. (1963). Developmental Biol. 7, 546.

Smithies, O. (1959). Biochem. J. 71, 585.

Swanson, M. A. (1955). In Methods in Enzymology, vol. 2, p. 541. Ed. by Colowick, S. P. \& Kaplan, N. O. New York: Academic Press Inc.

Ward, K. A. (1967). M.Sc. Thesis: University of Sydney.

Watson, M. L. \& Siekevitz, P. (1956). J. biophys. biochem. Cytol. 2, 639.

Williams, D. E. \& Reisfeld, R. A. (1964). Ann. N.Y. Acad. Sci. 121, 373. 